
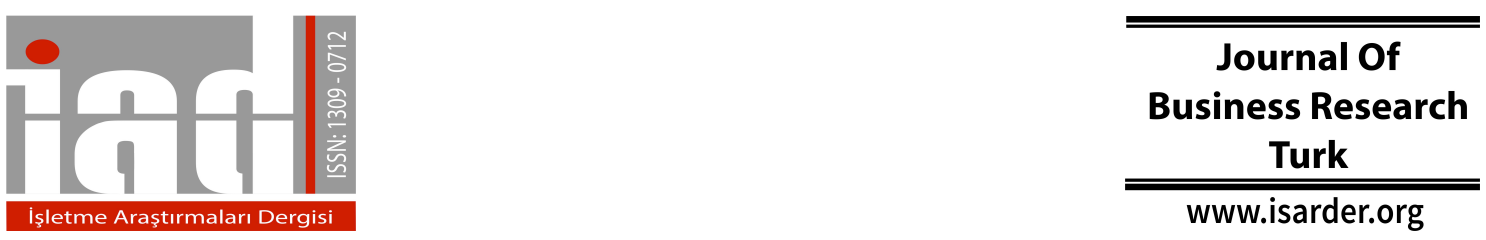

\title{
Consumer Behavior In The Process Of Purchasing Tourism Product In Social Media
}

\author{
Meltem ALTINAY \\ Arel University \\ Vocational School \\ İstanbul, Turkey \\ meltemaltinay@arel.edu.tr
}

\author{
Evren GÜÇER \\ Gazi University \\ Faculty of Tourism \\ Ankara, Turkey \\ evrengucer@gazi.edu.tr
}

\author{
Cennet BA $\breve{G}$ \\ Gazi University \\ Institute of Social Sciences \\ Ankara, Turkey \\ cennet.bag@gmail.com
}

\begin{abstract}
Today, with the development of communication technologies, the rate of use of the internet and web tools has also increased. The most preferred of this web-based tools has been social media. Because of using a lot, social media has become amarketing tool both in other fields and tourism industry. Consumers are affected the contents which is created by social media users or the company in case of purchase. Thus, a tourism product in social media how it is spoken is becoming important fur businesses. At this point, it must examined changes in consumer behavior in social media in the process of tourism product purchasing. This study aims to explore relationship with consumer behavior of social media in the process of tourism product purchasing. The research was applied 455 people use social media. For the analysis was applied SPSS 21.0. As a result of the data, it's appeared to be positive relationship between consumer behavior in prior and subsequent the purchase of tourism product and the level of social media usage.
\end{abstract}

Key words: Social media, Tourism Product, Process of purchasing, Consumer behavior

\section{Introduction}

Nowadays, rapid changes taking place in the technology and communication fields has brought the elimination of trade barriers in other words globalisation to the world. The internet manipulating the concept of time and space has served to the globalisation in this process (Erol, 2009, p. 34). In addition, globalisation activities has led to the creation of a compatitive environment not only in national but also in international arena in terms of marketing activities. So in this compatitive environment, the using of the internet and interactive tools named as social media in terms of marketing has became popular not only in the world but also in our country (Eröz and Doğdubay, 2012).

Through communication opportunities of our area, brands gives a variety of messages to consumers in order to attract attention and prevent competitors Tourism businesses just like brands benefits from marketing communication tools to convey their messages to both individuals and groups and also intermediaries. Some researchers state that the messages to be transmitted to consumers may be sent in the form of 
physical, verbal and virtual(viral) or a mixture of them (Jurvetson, 2000; Kaikati ve Kaikati, 2004). As long as the person buying any product or service has transferred the messages about this product/service to the other people, the introduction of the product or service is considered to have occured through rumor. As long as these messages spread by word of mouth are transmitted from person to person particularly in electronic media, the number of consumer reached grows like an avalanche. On the other hand, social media platforms provide more rapid dissemination of such rumors and hence the effects of rumors are more great (Özdemir and Sarı, 2014).

Social media is defined as the structure in which people interactively communicate and share their views each other on the net (Borges, 2009: 31), media platform and online applications seeking the sharing information and content, collaboration and easy interaction (Palmer and Lewis, 2009: 165), internet based tools and platforms enhancing and strengthening information sharing (www.socialmediadefined.com). Akar (2010, p.17) sees the social media as the web sites enabling deeper social interaction founded on web 2.0 technologies, community formation and the succeed of cooperation projects. According to the other approach, social media may be defined as social web sites providing the opportunity for participants to express themselves thorugh online media, to communicate, to participate in groups and to contribute with their opinion, comment and publications in this media (Köksal and Özdemir, 2013, p. 325).

Social media with characteristics features differing from traditional media can be summarized as an environment where is a high level of interaction providing the opportunity to create a content and to share these contents. However, social media has also a variety of interaction, sharing based environments serving to different aims with the different variety of content. Mangold and Faulds (2009, p. 358) organized social media platfroms as follows (Aydin, 2014):

- Social networking sites are websites where people create personal profile, meet virtually, communicate and contact with somebody who they know or not in real life (O'Connor, 2008). Social media sites varies according to the capabilities of sharing the photo and video (Boyd, Dannah and Ellison, 2007, p.211). Facebook is one of the most popular social networking sites.

- The sites creative works shared in are kind of video sharing sites (YouTube), photo sharing site (Flickr), music sharing sites (Jamendo.com), content sharing sites (Piczo.com), general intellectual data sharing sites (Creative Commons).

- User-assited blogs/microblogs are the web sites providing the oppurtinity for bloggers to log, share personal experiences and interests and interact with their readers through comments added on blog. The shares in these sites can be text, image, audio and video based (Kaplan and Haenlein, 2010, p.60). Micro-blogs are the limited character like Twitter and more text based sites.

- Firm-assisted web sites/blogs (Apple.com, P\&G's Vocalpoint).

- Firm-assisted goal oriented help sites (e.g. Dove's The Real Beauty Campaign).

- Networking sites for business (LinkedIn) provides their users to create the profile presenting professional features and to establish professional connection and networks (Papacharissi, 2009, p.200).

- Collaborative networking sites (Wikipedia) aim to bring together the society's knowledge and largely depend on user's content creation. They consist of two types of sites. These are wikis and social bookmark sites. Wikis are the 
community of information pages allowing to be made arrangements, resembling a dictionary, encyclopedia or database Social bookmark sites regulate, collect connection marks (Chan and Guillet, 2012, p. 48).

- Virtual worlds are online applications similar to real world created in threedimensional environments. These are sites where individuals represented by a photo or characters created like human contact in virtual world (Kaplan and Haenlein, 2009).

- Commercial communities (eBay, Amazon.com, Craig's List, iStockphoto, Threadless.com).

- News sites (Current TV).

Despite being separated by physical distance, social media users are connected with each other through similar interests, and content can be spread across the world within minutes. Social media also differs from traditional media in that audiences can customize content choices and interact with others (Chung, 2008). Marketing professionals recognize that advertisements shared among friends on social media Show more significant effects on brand awareness and purchase intent than the traditional marketing tools (Lee, 2010). Overall, social media can drive traffic more effectively (Kasavana et al., 2010), enhance customer loyalty and communication, is cost-effective (Brady, 2010) and also strengthens brand awareness and brand power (Edosomwan et al., 2011).

Gursoy and McCleary (2004) found that customers expend more effort trying to find information using the internet rather than traditional information resources, provided it is low-cost and accessible. Bhatnagar and Ghose's (2004) study indicated that the more time consumers spend on finding information on the internet, the more that information affects their decision making. Word-of-mouth has become especially important in the hospitality industry due to the intangibility and higher perceived risk. Electronic recommendations on these social media web sites assist consumers with their purchase decision, increase customers' satisfaction and give consumers positive brand images. A consumer decision process has four stages: consider, evaluate, buy, and advocate. Tourists go through these stages when making travel purchases, but social media has made the evaluate and advocate stages increasingly relevant (Hudson and Thal, 2013, p. 157). Tourism marketers need to consider the significance of those stages and use it to their advantage.

\section{Consumer Behavior in Tourism Product Purchasing Process in Social Media}

In the tourism context, many researchers have emphasized the effectiveness of social media, mostly considering it as a marketing tool and concentrating on the customer-company relationship. Litvin et al. (2008) suggested that online word-ofmouth on social media is a cost-effective marketing tool for hospitality companies. Kasavana et al. (2010) found that social media can bring both sides of the coin (customer loyalty and unfair criticism). Gretzel and Dinhopl (2014) and Gretzel and Fesenmaier (2012) examined how benefits of social media affect travelers' motivations to establish relationships with travel-related companies and destinations. However, theses studies focused only on the relationship between customers and the company, while the interaction among customers on social media was ignored. A few studies tried to examine social media from the customer's perspective, such as effects of online 
reviews (Ye et al., 2009; Vermeulen and Seegers, 2009) and customers' decisionmaking process (Fotis et al., 2012). So these studies increase day by day.

Tourism business need to have the organization applying the efforts to boost sales in the best way because tourism product's demand elasticity is hig. The purpose of aim to boost sales in tourism business is to inform them about business's product by attracting potential tourist mass's attention, to activate by creating trends and request about tourism products and to provide them to be purchased. In tourism, the efforts of boosting sales are carried out with help of personal selling, advertising, promotion, public relations and sales development tools. As another sales boosting tool, advertising activities creating opportunity to reach a wide audience are carried out in different ways and levels closely by linking to the state of competitors, the intensity of the competition (Bayazit Hayta, 2008). In this context, social media has a potential for tourism business as a promotion tool. In direct proportion to technological developments, the opportunity to obtain information about the tourism product showing increase in using social media is easily got. However, there is not any consensus about the role of social media being a newly-emerging field in marketing communication mix in terms of these promotional activities and there are many approaches to this topic (Köksal and Özdemir, 2013, p. 330). One of them; social media is involved in direct marketing with its speciality contecting directly to consumers and it is considered as a direct marketing channel (Palmer et al., 2009:166). Another approache is that "Social media is the member of new promotion mix"(Mangold and Lewis, 2009, p. 361).

As well as being labor-intensive sector, in tourism sector two important elements are human and technology that constantly change and become more important day by day (Uygur Medyan, 2007, p. 411). Technological developments provide becomming widespread of using internet in tourism sector, raise the awareness of consumers and affect consumer demand. In order to obtain a position in both national and international tourism market, it must be benefited from developing communication and marketing tools such as e-mail, SMS, internet, social media not from traditional marketind and promotional tools such ad newspaper, radio, television, telephone, catalog, brochures. In addition to this, today internet is the most commonly used of these modern communication tools in tourism marketing and it has been effective in many areas of marketing mix such as e-mail, consumer relations, providing information (Goeldner et al., 2011). So the internet is the new communication channel and it serves for manufacturers of tourism product and service and tourists (Law et al., 2004, p. 100). Therefore, it affects tourists' holiday decisions (Minghenti et al., 2010, p. 268). So the developments on net are one of the biggest factors in travel experiences, tourist's purchasing behavior, travel agencies and the development and the change in tourism (Shih, 2009).

The consumers decide by benefiting from visitors' previous experiences on the social media platforms such as Facebook, Twitter, Google Plus, Flickr, Picasa, YouTube and Blog pages and they think visitors' experiences shared are more real than traditional marketing tools (Wheeler, 2012, p. 11). Since tourism is the service sector, being affected by different people's experiences and advices is so high as well as tourism products have different qualities from physical products (Eröz and Doğdubay, 2012, p. 138).

The fellow consumer opinion is often more influential than marketers efforts to 
persuade consumers. Customer reviews that allow for consumer-to-consumer interaction, can be found directly on tourism company websites, company blogs, sites such as TripAdvisor.com, or personal blogs (Hudson and Thal, 2013, p. 158). Social media has become a crucial tool to change the paradigms of marketing strategies in the hospitality industry and tourism sector as well. Hospitality and tourism businesses have increasingly incorporated social media into their marketing tools to reduce marketing costs, create a strong reputation (Mohamed, 2012) and expand their market share (Thomas, 2010). More importantly, developing marketing strategies for social media is essential for strengthening relationships with customers by invigorating the valuecreation network.

Social media has shown its ability to increase customer intimacy by allowing continuous mutual communications between tourism businesses and customers (Saperstein and Hastings, 2010). Customers are also engaged with each other in organizing contents, sharing their opinions and in turn influencing others' awareness and loyalty level toward hospitality brands (Blackshaw and Nazzaro, 2006) because social media plays an important role as a key information channel (Xiang and Gretzel, 2010; Xiang et al., 2008).

When the comments made in internet environment are considered to help reducing the risk of deciding the destination and with this reason to make deciding easier in the decision-making period of consumer, these comments mean that the alternatives are limited before travel and so they help making destination selection easier and truer (Gretzel, Yoo and Purifoy, 2007). Social media, as well as sharing this comment and information, offers the sharing opportunity of holiday experiences to travellers during travel (Gretzel, Fesenmaier and O'leary, 2006, p.12). In this way, social media being the most popular information channel is favourite for travellers.According to the data of Traveller ipsos in 2012, $83 \%$ of travellers for holiday in America and $76 \%$ of travellers for business make travel decision with the informations obtained on net. The most used platforms for obtaining information are travel agents' web sites, destinations' and business' web sites and search engines (Akyol and Kılınç, 2014, p. 178). According to the data collected by Ipsos MediaCT in 2013 , more than $60 \%$ of travellers search on Google before making decision, rely on the travellers' experiences and they are influenced by video and photos shared during travel. Social media effects tourism marketing since it is the platform mentioning the complaints of travellers and the services to be demanded. The demand to the business and the destination market can diminish because the negative comments are made for any tourism business or destination. With technological developments, now many business provide the market promotion through the advertisements made in social media. Due to the comments, the marketing process is affected and the sustainability of the business's marketing tourism product differs too. The users affected from the photo sharing, video shoots, comments and other sharings can chose the tourism business being source of these sharings. So this shows that the sharings in social media have an effect on the sustainability of tourism business' marketing product. In this regard, social media provides the opportunities creating new chance to the business in tourism sector. Tour operators, potential consumers, producers, toursits benefit from social media to evaluate product, service and other activities, to ask question, to criticize and to make decision (Bizirgianni and Dionysopouloub, 2013, p. 652). Social media can cause decreasing of travel agents' sales rate as well as these opportunities. The platforms in 
social media also can cause losing tour operators and travek agents' importance (Buhalis and Licata, 2002, p. 214). It is used with the aim of arousing interest to hotel, introducing the promotions, enabling meeting with guests in a warm atmosphere, following the factors making them happy or unhappy, arousing interest to the brand, attracting the media's attention, creating or increasing brand awareness and the most important one contacting with guests in a warm atmosphere (Bozatl1, 2014).

The formation process of travel experiences for a tourist consumer in the social media consists of three different stages. These steps are as follows (Milano, Baggio and Piattelli, 2011,p. 4):

- Past experience: It is made up of travel stories of other people. It provides information before making a travel decision for the tourist consumer.

- Experience in travel and accommodation: In parallel with the advances in information and communication technologies, Tourism consumers can share real-time experiences with mobile applications on social media platforms.

- Travel and post-stay experience: It contains tourism consumers' travel experiences, their comments on post-travel social meadia platforms, their evaluations and the expressions they express.

The pre-purchase stage or past experience refers to the time when preliminaries occur. Customers make their purchasing decision during the pre-purchase stage of service based on an evaluation of information received (Lovelock, 2011; Tsiotsou and Wirtz, 2012). The pre-purchase decision-making process involves various factors, activities and consumer participation, and thus is considered more complex and requires more time to complete than that required when buying goods (Fisk, 1981). The postprocess stage or post-stay experience is the termination of the service at the end. Consumers evaluate their satisfaction level and the service quality at the end of the service consumption process (Dube-Rioux et al., 1989). In the pre-purchase stage, the customers' needs guide their information search. Making a decision in a service context involves a high degree of uncertainty, thus customers spend an extended length of time retrieving information in an effort to reduce their risk (Mattila and Wirtz, 2002). The internet has reshaped customers'decisions when they find information and plan their vacations. The dominant approach to researching service information in the hospitality industry is via the internet due to the enormous amount of data available (Xiang and Gretzel, 2010). As consumers search information in the pre-purchase stage, they also start considering the service attributes they want or prefer. Once key attributes are decided, customers begin making their decisions to purchase according to the evaluation of these attributes. After customers evaluate these attributes and compared to other possible alternatives, they are ready to make a decision to purchase (Tsiotsou and Wirtz, 2012).

The social media channels, which provide smaller advertising budgets than the other commercial channels for tourism enterprises, where the financial resources are largely limited by the large majority of SMEs, offer significant competitive advantage to businesses in terms of tourism marketing (Živković, Gajić and Brdar, 2014). Today, there are new additions to the channels such as Facebook, Twitter, Instagram, Youtube, Vkontakte (Russia) Google Plus, Foursquare, Youtube which are used by the tourism sector. On the other hand, sites such as HolidayCheck, TripAdvisor, Zoover, which provide more evaluation and reputation management, and price comparison sites are 
also considered social media tools (Turizm ve Yatırım Dergisi, 2014). Tourists share vacation experiences with such social media tools and holiday planners have the opportunity to access this information from the very beginning. It is known that holiday experiences that sprang from the mouth in social media tools - whether positive or negative - affect tourists' preferences for vacation and tourism businesses. These comments are made on social media sites that are not intended for commercial purposes is found reliable for tourists (Erol and Hassan, 2014).

In the same way, today's tourists are more interested in their consumption style, which is part of the traveling period that they are experiencing and makes them happy by making this period meaningful. For example; It is more attractive to get intangible and tangible benefits from it than to have a gift for a tourist during the holiday. Instead of a physical object to be purchased for the moment; with the sharing of the lived moments with others and their sharing of a picture of the nature of the social media, the experiences of tourists are getting better meanings (www.aktuelmarmaris.com, 06.12.2016).

Social media tools can influence tourists' behavior, and they can be used at every stage of tourist travel. Many businesses that are aware of this fact and offer services and products based on tourism, are evaluating this feature of social media tools in order to increase their profitability. For example, many airline businesses that aim to develop effective marketing strategies with social media tools, publish promotional films on Youtube and offer attractive flight offers to potential tourists on social networks like Loopt. Nowadays, a traveling person can plan every journey that makes up the journey from booking a restaurant to a food restaurant through the internet and its social media tools, which is an important component. For example; Delta Airlines tickets can be purchased via Facebook. It is not just airline businesses that want to increase the level of direct sales using social media tools. Accommodation businesses such as Morgan Hotel, which follow an effective marketing and sales development strategy using these tools, use Foursquare social media tool to win Twitter and Facebook users as customers, not to distract their customers and increase their sales. Morgan Hotel invites its chain operators to check in at the airports in the cities where they are located and to send them last minute deals via Foursquare (Eröz and Doğdubay, 2012).

Given the nature of social media marketing tools, it seems that travel blogs and social networking tools are more effective in this respect (www.mustafakirca.com, 06.12.2016). The research done by Hays, Page and Buhalis (2012) also supports this finding. The study was conducted to determine the extent to which social media contributed to the destination marketing of the 10 most visited countries by foreign tourists. As a result of research, Facebook, seen as a social media network, was found to be more effective in destination marketing than other social media application tools. It is emphasized here that the development of social media and social media strategies is important for successful long-term and future oriented marketing (Güleç, 2016).

\section{Method}

\subsection{The Importance of the study}

Social media platforms form the existence of the culture arising from the members' social interaction in virtual environment and being in progress. The members of this culture have not only passive information consumers identity. The members are active also in producing information (Kienle et al., 2010). It can be said that today 
social media having an important role about sharing information fastly and actively is one of the factors effecting the decision of tourism product and service. So the important one about the sustainability of marketing tourism product is searching the influence of social media. The consumers want to remove the uncertainties about deciding product and service generally by using social media as an information channel before purchasing tourstic product and service. In short, they think the content consisting of visitors' experiences is more reliable and realist than traditional marketing materials (Wheeler, 2009). This study is a follow-up of the researches done in this area and offers more recent data. This brings the necessity of the study into the forefront.

\subsection{Aim of the study}

The aim of the study is to research and reveal how the social media affects the consumer behavior about tourism product. With this study, it is aimed to reveal how often social media is used and which social media tool is used. Also, the other aims of the study are to reveal whether there is any difference in the consumer's behavior between pre-purchasing and post-purchasing or not according to users' demographic features and to test whether there is a positive relation between the rate of using social media and consumer's behavior before and after purchasing tourism product or not.

\subsection{Population and sample}

Social media contains online environments where the users have different demographic features. Consumers who use social media want to research and get information about tourist products before purchasing tourist products and then they want to spread their satisfaction and thoughts on the social media. Therefore, the population of research is composed of 42 million people who have different demographic characteristics and actively use social media tools in Turkey. However, because it is almost impossible to reach all of the persons covered by this definition, sampling in the research was deemed appropriate. In this research, which uses simple random sampling method because it represents the population, the sample is calculated as 384 and the sample is 455 people using social media platforms.

\subsection{Data collection method}

In the study, questionnaire study was made as a data collection method. In the process of preparing survey questions, İşlek (2012) scale was used. The questionnaire includes totaly 23 statements with the demographic questionsand three categories. In the first category of the questionnaire, there are some judgements about demographic features. In the second category, there are some statements surveying the behavior pattern before purchasing tourism product in social media. In third category, there are some statements surveying the behavior pattern after purchasing tourism product in social media. The questionnaire was formed by using Google Documents and the participants' attendance is aimed by sending the link of the questionnaire to social media tools such as Facebook, Twitter, Blogs and Forms. 455 social media users attended to the questionnaire published between 01.10.2014 and 01.12.2014 and responded all the question Within the study the data obtained from the questionnaire survey was analyzed by using SPSS 21.0 package.

\subsection{The hypothesises of the study}

Since social media users are likely to differ in their social media use levels and goals according to their demographic characteristics, one of the research hypotheses is "H1: There is a meaningful difference between demographic factors and consumer behavior 
in the social media purchasing process of tourism products. With the increase of technology possibilities, the increase of social media users and their different demographic characteristics can cause the preferences of various tourism products they want to purchase. Many factors, such as age, gender, marital status, level of education, social media tools, etc. of social media users can lead to changes in consumer behaviors before and after the purchase of tourism products. The reason for the development of the hypothesis is that "H2: There is a positive relationship between the level of social media use and consumer behavior in the social media purchasing process of tourism products", which constitutes the second hypothesis of the research, It is thought that the individuals using the social media tool examine the tourism product purchasing processes and the usage rates of the social media platforms are effective in the tourism product purchasing process, along with there are few studies that currently examine consumer behavior in the tourist product purchasing process.

\subsection{Analysis of data}

Since one of the research aims is to examine the relationship between the demographic characteristics of social media users and consumer behavior in the social media purchasing process of tourist products, analysis techniques have been applied to analyze the relationships in the analysis of the data. In the univariate analyzes used, frequency distribution of data and arithmetic mean values and standard deviation values were analyzed. With the help of arithmetic average values, consumers' behaviors in the social media purchasing process of tourism products were tried to be determined. T-test, variance (ANOVA) analysis from parametric tests for hypotheses were used. And also A collage analysis was conducted to clarify the relationship between the level of social media usage and the consumer's behavior in the social media purchasing process of tourist products for another goal of the research. In the reliability analysis, the Cronbach's alpha value of the questionnaire was 0.91 , because this value is between $0.80<\alpha<1$, 1t indicates that the survey scale is highly reliable.

\section{Findings}

\subsection{The scale reliability}

The reliability analysis of the scale testing the effetcs of social media on choosing tourism product and service is calculated by Cronbach's Alpha coefficient. As relating to the scale's general reliability, it was found that the alpha value of the statements related to the effects of social media on consumer's pre-purchasing behavior was $=0,856$ and $=0,896$ for consumer's post-purchasing behavior. This shows that our study's reliability is high.

Table 1.The scale reliability

\begin{tabular}{lcc}
\hline Scale & $\begin{array}{c}\text { Number } \\
\text { of items }\end{array}$ & $\begin{array}{c}\text { Cronbach } \\
\text { Alpha } \\
\text { Coefficient }\end{array}$ \\
\hline $\begin{array}{l}\text { The statements relating to consumer's pre-purchasing } \\
\text { behavior on social media } \\
\begin{array}{l}\text { The statements relating to consumer's post-purchasing } \\
\text { behavior on social media }\end{array}\end{array}$ & $\mathbf{8}$ & $\mathbf{0 , 8 5 6}$ \\
\hline $\begin{array}{l}\text { The statements relating to consumer's purchasing behavior } \\
\text { on social media }\end{array}$ & $\mathbf{1 6}$ & $\mathbf{0 , 9 9 6}$ \\
\hline
\end{tabular}




\subsection{Demographic Features}

$49,7 \%$ of 455 people participating in the questionnaire was male and $50,3 \%$ of them was female. When we looked at the range of sample's age group, it was seen that $0,9 \%$ was 18 years and below, $49,2 \%$ was $19-24$ years, $35,2 \%$ was $25-30$ years, $7,9 \%$ was $31-36$ years, $3,3 \%$ was $37-42$ years, $2 \%$ was $43-47$ years, $0,7 \%$ was $48-53$ years, $0,7 \%$ was $54-59$ years and $0,2 \%$ was $60-65$ years. As we understood from the table, the average of the visitors' age was between 19 years and 24 years. 83,1\% of participants in study was bachelor, $11,2 \%$ of them was married with children and $5,7 \%$ was married with no children. The state of sample's education was that $0,2 \%$ was primary education, $2,9 \%$ was high school, 3,5\% was associate degre, $56,9 \%$ was undergraduate, $32,7 \%$ was post graduate and 3,7\% was doctor's degree. According to our sample's country, the income state was that $2,2 \%$ was very low, $16,5 \%$ was low, $72,1 \%$ was middle, $8,4 \%$ was high and $0,9 \%$ was very high. So the income state is on average according to the country stayied. While $25,7 \%$ of the sample weekly used social media $0-5$ hours, $23,7 \%$ 6-10 hours, the range social sharing web sites used by the sample was like; $97,1 \%$ Facebook, 49,7\% Twitter, 80,4\% YouTube, 44,6\% Instagram, 10,8\% Blogs, 20,2\% Foursquare, 32,7\% Forms and dictionary, 22,2\% Google + and 20,2\% others. It was showed the range of the sample's features in Table 1. As seen from Table 1, the most commonly used social media platforms were Facebook and YouTube. The majority of social media users participating in the survey, such as Eryılmaz and Zengin (2014) are in the research they have done, are single, aged between 19-30 and bachelor. In addition to this, the most popular social media platform has been as Facebook

Table 2. The Profile of Sample

\begin{tabular}{|c|c|c|c|}
\hline & $\begin{array}{l}\text { Socio-Demographic } \\
\text { Variables }\end{array}$ & $\mathbf{n}$ & $\%$ \\
\hline \multirow[t]{2}{*}{ Gender } & Male & 226 & 49,7 \\
\hline & Female & 229 & 50,3 \\
\hline \multirow{9}{*}{ Age } & 18 and below & 4 & 9 \\
\hline & $19-24$ & 224 & 49,2 \\
\hline & $25-30$ & 160 & 35,2 \\
\hline & $31-36$ & 36 & 7,9 \\
\hline & $37-42$ & 15 & 3,3 \\
\hline & $43-47$ & 9 & 2,0 \\
\hline & $48-53$ & 3 & ,7 \\
\hline & $54-59$ & 3 & ,7 \\
\hline & $60-65$ & 1 & 2 \\
\hline \multirow[t]{3}{*}{ Marital Status } & Bachelor & 378 & 83,1 \\
\hline & Married with children & 51 & 11,2 \\
\hline & $\begin{array}{l}\text { Married with no } \\
\text { children }\end{array}$ & 26 & 5,7 \\
\hline \multirow[t]{3}{*}{ Education Status } & Primary school & 1 & ,2 \\
\hline & Secondary school & 13 & 2,9 \\
\hline & Associate degree & 16 & 3,5 \\
\hline
\end{tabular}


M. Altınay - E. Güçer - C. Bağ 9/1 (2017) 381-402

\begin{tabular}{|c|c|c|c|}
\hline & Undergraduate & 259 & 56,9 \\
\hline & Postgraduate & 149 & 32,7 \\
\hline & Doctorate & 17 & 3,7 \\
\hline \multirow{5}{*}{ Income Status } & Very low & 10 & 2,2 \\
\hline & Low & 75 & 16,5 \\
\hline & Middle & 328 & 72,1 \\
\hline & High & 38 & 8,4 \\
\hline & Very high & 4 & ,9 \\
\hline \multirow{8}{*}{$\begin{array}{l}\text { Weekly use } \\
\text { frequency }\end{array}$} & $0-5$ & 117 & 25,7 \\
\hline & $6-10$ & 107 & 23,5 \\
\hline & $11-15$ & 72 & 15,8 \\
\hline & $16-20$ & 59 & 13,0 \\
\hline & $21-25$ & 40 & 8,8 \\
\hline & $26-30$ & 23 & 5,1 \\
\hline & 31 and above & 37 & 8,1 \\
\hline & Facebook & 442 & 97,1 \\
\hline \multirow[t]{8}{*}{ Social media tools } & Twitter & 226 & 49,7 \\
\hline & YouTube & 366 & 80,4 \\
\hline & Instagram & 203 & 44,6 \\
\hline & Blog & 49 & 10,8 \\
\hline & Foursquare & 92 & 20,2 \\
\hline & $\begin{array}{l}\text { Forums } \\
\text { Dictionaries }\end{array}$ & 149 & 32,7 \\
\hline & Google + & 101 & 22,2 \\
\hline & Other & 92 & 20,2 \\
\hline
\end{tabular}

\subsection{The Assessments Related to Consumer Behavior Being in the Process of Purchasing Tourism Product in Social Media}

The answer options were created by using 5 point likert scale. While 1 of the options means "disagree", 5 means "strongly agree". 3 option being mid-point means "partially agree" or "neither agree or disagree" . According to this, the mean and the standard deviation of the answers to the judgements about consumer's pre-purchasing behavior was showed in the table below. As seen in Table 3, the judgement "I searche in the social media about that product/service before buying a product" had the highest average with 3,79 as a result of frequency analysis. Again as a result of frequency analysis, the judgement "I care about the advices of popular users in social media about tourism product/service" had the lowest average with 2,80 . The judgement relating to pre-purchasing of tourism product with the highest average was "If I am not pleased with the tourism product/service, I share this in social media". The lowest one $(2,83)$ was "If I am pleased with the tourism product/service, I share this in business's web site in social media". Consequently when the judgements related to marketing tourism product and purchasing process in social media had been examined, we could say that 
social media users firstly searched the products in social media and they shared the dissatisfaction about the product in social media. In the same way, we could say thay social media users didn't care about the advices of popular users in social media while purchasing tourism products. After purchasing, it was observed that their dissatisfaction about the product was shared in social media but not the satisfaction.

Table 3. The Arithmetic Mean of The Expressions

\begin{tabular}{|c|c|c|c|}
\hline $\begin{array}{l}\text { The Expressions Related to Consumer's Purchasing } \\
\text { Behavior in Social Media }\end{array}$ & \multirow[t]{2}{*}{$\mathbf{n}$} & \multirow[t]{2}{*}{ Mean. } & \multirow[t]{2}{*}{ S.D } \\
\hline Pre-Purchasing & & & \\
\hline $\begin{array}{l}\text { Before buying a tourism product and service, I search in the } \\
\text { social media about that product/service. }\end{array}$ & 455 & 3,79 & 1,21 \\
\hline $\begin{array}{l}\text { I belive that I find the reliable informaiton in soical media about } \\
\text { tourism product/service. }\end{array}$ & 455 & 3,21 & 1,06 \\
\hline $\begin{array}{l}\text { If the informaiton about tourism product/service in social media } \\
\text { is created by a consumer, I rely on this information }\end{array}$ & 455 & 3,41 & 1,03 \\
\hline $\begin{array}{l}\text { I care about the people's advices just who I know before about } \\
\text { tourism product/service in social media. }\end{array}$ & 455 & 3,37 & 1,17 \\
\hline $\begin{array}{l}\text { I care about the advices of the popular social media users about } \\
\text { tourism product/service in social media. }\end{array}$ & 455 & 2,80 & 1,19 \\
\hline $\begin{array}{l}\text { I prefer buying the products and services of tourism business } \\
\text { which I like and follow in social media tools. }\end{array}$ & 455 & 3,26 & 1,11 \\
\hline $\begin{array}{l}\text { Tourism business's getting in contact with me has a positive } \\
\text { effect on me for purchasing. }\end{array}$ & 455 & 3,08 & 1,26 \\
\hline $\begin{array}{l}\text { Social media sites are the suitable platforms for tourism business } \\
\text { in order to get in contact with the consumers. }\end{array}$ & 455 & 3,27 & 1,17 \\
\hline Post-Purchasing & \multirow[b]{2}{*}{455} & \multirow[b]{2}{*}{3,30} & \multirow[b]{2}{*}{1,22} \\
\hline $\begin{array}{l}\text { If I am pleased with the tourism product/service, I share this in } \\
\text { social media. }\end{array}$ & & & \\
\hline $\begin{array}{l}\text { If I am pleased with the tourism product/service, I share this in } \\
\text { the company's websites in social media. }\end{array}$ & 455 & 2,83 & 1,20 \\
\hline $\begin{array}{l}\text { If I am not pleased with the tourism product/service, I share this } \\
\text { in social media. }\end{array}$ & 455 & $\mathbf{3 , 5 0}$ & 1,27 \\
\hline $\begin{array}{l}\text { If I am not pleased with the tourism product/service, I share this } \\
\text { in the company's websites in social media. }\end{array}$ & 455 & 3,25 & 1,30 \\
\hline $\begin{array}{l}\text { If I am pleased with the tourism product/service, I recommend } \\
\text { other users to buy this product in social media. }\end{array}$ & 455 & 3,37 & 1,17 \\
\hline $\begin{array}{l}\text { If I am not pleased with the tourism product/service, I } \\
\text { recommend other users not to buy this product in social media. }\end{array}$ & 455 & 3,48 & 1,24 \\
\hline $\begin{array}{l}\text { Being realized by the tourism business whose tourism } \\
\text { product/service I am pleased with raise my satisfaction. }\end{array}$ & 455 & 3,46 & 1,23 \\
\hline $\begin{array}{l}\text { If the tourism business which I am not pleased with realize me } \\
\text { and get in contact with me, I can change my opinion. }\end{array}$ & 455 & 3,10 & 1,23 \\
\hline
\end{tabular}


Table 4. Income Status, Consumer Behavior Before and After Purchasing Tourism Product in Social Media

\begin{tabular}{|c|c|c|c|c|c|c|c|c|c|}
\hline \multirow{3}{*}{${ }^{*} \mathbf{p}<0,05$} & \multirow{3}{*}{$\mathbf{n}$} & \multirow{3}{*}{ mean. } & \multirow{3}{*}{ S.d } & \multicolumn{6}{|c|}{ Anova Test } \\
\hline & & & & \multicolumn{2}{|c|}{$\begin{array}{c}\text { Pre- } \\
\text { Purchasing }\end{array}$} & \multicolumn{2}{|c|}{$\begin{array}{c}\text { Post- } \\
\text { Purchasing }\end{array}$} & \multicolumn{2}{|c|}{$\begin{array}{c}\text { Purchasing } \\
\text { Process }\end{array}$} \\
\hline & & & & f & p & f & p & f & $\mathbf{p}$ \\
\hline Çok Düşük & 10 & 3,25 & 0,94 & \multirow{5}{*}{2,546} & \multirow{5}{*}{, $03 *$} & \multirow{5}{*}{1,370} & \multirow{5}{*}{, 24} & \multirow{5}{*}{2,122} & \multirow{5}{*}{, 07} \\
\hline Düşük & 75 & 3,12 & 0,79 & & & & & & \\
\hline Orta & 328 & 3,28 & 0,80 & & & & & & \\
\hline Yüksek & 38 & 3,58 & 0,70 & & & & & & \\
\hline Çok Yüksek & 4 & 3,15 & 0,21 & & & & & & \\
\hline
\end{tabular}

When the responses given to consumer behavior expressions were compared prepurchasing tourist products in the social media according to income level in the region where the sample resides, social media users who participated in the survey differ significantly in their responses to consumer behavior expressions pre-purchasing tourist products in social media by income levels according to the results of Anova test $p=$ $0.03<0.05$. However, $24>0.05$ means that consumer behavior in social media postpurchasing does not differ according to income level. When the purchasing process is examined in general, it is seen that there is no change according to the level of consumer behavior income in the tourism product purchasing process in social media (Table 4).

Table 5. Education Status, Consumer Behavior Before and After Purchasing Tourism Product in Social Media

\begin{tabular}{|c|c|c|c|c|c|c|c|c|c|}
\hline \multirow{3}{*}{${ }^{*} \mathbf{p}<0,05$} & \multirow{3}{*}{$\mathbf{n}$} & \multirow{3}{*}{ mean. } & \multirow{3}{*}{ S.d } & \multicolumn{6}{|c|}{ Anova Test } \\
\hline & & & & \multicolumn{2}{|c|}{$\begin{array}{c}\text { Pre- } \\
\text { Purchasing } \\
\end{array}$} & \multicolumn{2}{|c|}{$\begin{array}{c}\text { Post- } \\
\text { Purchasing }\end{array}$} & \multicolumn{2}{|c|}{$\begin{array}{c}\text { Purchasing } \\
\text { Process }\end{array}$} \\
\hline & & & & $\mathbf{f}$ & $\mathbf{p}$ & $\mathbf{f}$ & $\mathbf{p}$ & $\mathbf{f}$ & $\mathbf{p}$ \\
\hline $\begin{array}{l}\text { Primary } \\
\text { school }\end{array}$ & 1 & 2,75 & . & \multirow{6}{*}{2,926} & \multirow{6}{*}{, $01 *$} & \multirow{6}{*}{2,099} & \multirow{6}{*}{, 064} & \multirow{6}{*}{2,815} & \multirow{6}{*}{, $01 *$} \\
\hline High school & 13 & 2,52 & 1,39 & & & & & & \\
\hline $\begin{array}{l}\text { Associate } \\
\text { degree }\end{array}$ & 16 & 3,27 & 1,13 & & & & & & \\
\hline Undergraduate & 259 & 3,27 & 0,75 & & & & & & \\
\hline Postgraduate & 149 & 3,36 & 0,74 & & & & & & \\
\hline Doctorate & 17 & 3,37 & 0,57 & & & & & & \\
\hline
\end{tabular}


According to the results of Anova test, the sample's answers given to the expressions about consumer behavior in purchasing process in social media in terms of education status showed a meaningful change. However, this differentiation was seen only in pre-purchasing $(0,01)$. With this differentiation, it was seen a change in general purchasing process. According to users' education status variable, it was seen that there were important differences in their behaviors in purchasing tourism product process (Table 5).

As a result of the findings, according to the demographic characteristics except education and income level, there is no statistically significant difference between consumer behaviors during the tourism product purchasing process in social media. In terms of income levels, the high-income social media users in pre-purchasing process of tourism products tend to do more research in social media compared to low incomes. As a result, the behavior of social media users in pre-purchasing has changed in terms of income levels. In terms of the level of education, most of the social media users participating in the survey are undergraduates. Especially in the pre-purchasing process, it is seen that the users try to collect information about tourist products in social media. Along with that It seems that the consumer behavior in the pre-purchasing process in social media differs according to the level of education. In PostHoc analysis to see which groups of differentiation exist, Since the number of individuals in a group was less than 2, it was not possible to find out which groups differed. As a result of the difference analysis for other demographic variables, It appeared that there is no differentiation between gender, age, marital status, the duration of social media usage and consumer behavior in tourism products purchasing process in the social media. For this reason, there is no difference in social media users' gender, age, marital status and duration of social media usage, in the process of purchasing tourist products in social media. However, the difference in education and income situation partially confirms the hypothesis "H1: There is a statistically significant difference between demographic factors and consumer behavior in the social media purchasing process of tourism products." When we look at the work done about the subject; Eryılmaz and Zengin (2014), "A Study on Consumer Approaches to Accommodation Operations in Social Media", shows that consumer attitudes towards social media sharing do not differ according to their demographic characteristics. Sharp and Head (2015), according to what they have done; The result has emerged that female consumers were affected by the comments made in social media tools more than male consumers and changed their opinions. As a result of the thesis that İslek (2012) made "Social Media Effects on Consumer Behaviors: A Research on Social Media Users in Turkey", No differences were found in demographic factors in terms of gender, age groups and education level in consumer behavior pre and post-purchasing in social media. 
Table 6. The Correlation Between Social Media Purchasing Processes In Terms of Weekly Use of Social Media and Tourism Products

\begin{tabular}{|l|c|c|c|}
\hline & $\begin{array}{l}\text { Social media } \\
\text { use frequency }\end{array}$ & $\begin{array}{l}\text { Consumer } \\
\text { behavior before } \\
\text { purchasing in } \\
\text { social media }\end{array}$ & $\begin{array}{l}\text { Consumer } \\
\text { behavior after } \\
\text { purchasing in } \\
\text { social media. }\end{array}$ \\
\hline Social media use frequency & 1 &, $865^{*}$ &, $750^{*}$ \\
\hline $\begin{array}{l}\text { Consumer behavior before } \\
\text { purchasing in social media }\end{array}$ &, $865^{*}$ & 1 &, $645^{*}$ \\
\hline $\begin{array}{l}\text { Consumer behavior after } \\
\text { purchasing in social media. }\end{array}$ &, $750^{*}$ &, $645^{*}$ & 1 \\
\hline
\end{tabular}

In this study, the another of the aims was to examine whether there was a relation between social media use frequency and the effects of social media on purchasing process in terms of tourism product or not. In this context, the pearson's correlation coefficient was used in order to measure the relation between social media use frequency and the effects of social media on purchasing process in terms of tourism (Table 6). According to the Pearson value, Sig. ( 2 tailed) was 0,000 . Because this value was like $p<0,01$, there was a linear relationship between social media use frequency and consumer behavior before and after purchasing tourism product in social media. It was found that the correlation coefficient bewtween social media use frequency and consumer behavior before and after purchasing tourism product in social media was ,865. This stuation showed us there was a positively high relation. So the level of response of social medai users making tourism product choice would increase as long as social media use frequence increased. It was found that correlation value between consumer behavior after purchasing and social media use frequency was ,750. As being in pre-purchasing, there was a high relation between social media use frequency in postpurchasing. With these data, the $\mathrm{H} 2$ hypothesis "There is a positively relation between social media use frequency and consumer behavior before and after purchasing tourism product" was supported. According to this result, as long as the social media use frequency increases, the frequency of people's sharing their satisfaction or dissatisfaction about toursitic product in social media is increasing. According to the data, there was a positive relation between consumer's pre and post purchasing $(, 645)$. It is undertood from this relation that the more research is done about any tourism product before purchasing, the more importance is given to experiences shared and the more increase is in possibility of users' sharing their satisfaction or dissatisfaction after purchasing in social media.

There are many studies on social media and tourism relation in the literature. From the prominent ones that support the results of this work; it can given that the study shows that Web 2.0 applications are not the only ones that travelers refer to but are an important resource (Cox et al. 2009), the study (Fotis et al., 2011) that social media is mostly used after travel to share experiences, the study (Bizirgianni and Dionysopoulou, 2013) that young tourists use social media to learn about photography, video, sharing experiences and use these information to make travel decisions and the study about consumer approaches to managing accommodation in social media (Ery1lmaz and Zengin, 2014). 
According to Bayram et al. (2016), Hotel enterprises first shared their food and beverages in social media, while the second plan is sharing views and hotel services. According to Toksari et al. (2014), it is parallel in accordance with the findings. According to the study, the most used platform is Facebook. In addition to this, social media users have expressed their friends' share and follow the well-known brands. However, according to the results of their work on Facebook ads by Kazançoğlu et al. (2012), The inability of Facebook advertisers to create a positive attitude for their users is the result of not buying any products or brands that individuals see on their Facebook ads. This negative attitude stems from the fact that Facebook is used by users for social sharing rather than by obtaining information about products or brands. Battallar and Cömert (2015) have been chosen as the most used platform in the studies that they have done on the effects of advertisements in social media in consumers' preferences. In addition to this, it is mentioned that this platform is used for both advertising activities and socialization. In addition, Battallar and Cömert stated that students from both state and foundation universities will participate in campaigns organized by social media enterprises and evaluate business promotions received by mail. As you can see from this, social media users are trying to reach the necessary information on platforms where they can reach social media for the products they are interested in. On thw other studies on tourism and social media, it has been found that Pietro, Virgilio and Pantano (2012) have different behaviors in social media before, during and after holiday. According to the studies of Çetinsöz et al. (2015) and Fotis et al. (2012), the participants' social media usage attitudes were mostly evaluated by social media usage and evaluation process before the holiday. It was also determined in the research results that participants could also influence their decisions about social media use attitudes prior to the holiday. It was also determined that participants used social media during each holiday period during the general holiday process. In addition to this, Aymankuy et al. (2013) 's work has reached the result that social media influenced vacation decisions before the holiday of domestic tourists. Erol and Hassan (2014) have shown that young people are partly influenced by social media in their vacation decisions in their study of determining the impact of social media on holiday preferences. Rather during the holidays Rathonyi (2013) a largely untouched result, has come to the conclusion that tourists intensively use social media before touring. Besides, in his study, it is found that tourists' friends and relatives are the most reliable source of information and that the reliability of information obtained from social media is lowest compared to others. Pesonen (2012) assessed tourists' purchasing behavior through some social media channels.

\section{Conclusion}

Technology is develoing day by day. As well as this development, the fields of using mass media are developing also. The advertisement being a promotional factor is always necessary for business to be able to contain their activities. So every sector and business adversiting follow closely the developments in the world. Social media becomes being the important factor of these advertisement tools. Social media which helps consumers get information about all topics has advantage for business to introduce themselves.

Thanks to the developments, social media having an important place in every part of our life has an important place also in tourism sector. The consumers can get new informations about product and services apart from the marketing messages of tourism 
business. Because these informations are formed by consumers again, they are seen as an important source of information in terms of consumer. It is possible to say that the consumer behavior varies with the sharing experiences in social media platforms as a result of this kind of communication and interaction. In this study, it was tried to state how the social media affects purchasing process, to reveal how consumer behavior is before and after purchasing and to state whether these consumer behaviors differ according to socio-demographic variables or not. For this purpose, at first social media users are asked to reply to the expressions revealing how often they use social media and which social media tools are used. The range of the participants' social media use frequency in the study is respectively Facebook, YouTube, Twitter, Instagram, Forums and Dictionaries, Google+, Blog and others. Facebook of these social media platforms is the most used platform because of being prefered by 442 participants. It shows that Facebook is the most used platform for preference of tourism product and sharings made. The others used mostly are YouTube, Twitter and Instagram. According to these results, the tourism business must take place in the social media tools used mostly by potential consumers with their corporate identity. Social media users use the social media with the aim of collecting information. So they mostly agreed with the expression "Before I buy a tourism product and service, I search on social media about this product/service". Besides, the expression "If I am not pleased with tourism product/service, I share this in social media" has the second most intense participation. Accordingly, the positive or negative comments in social media affect on consumer's decisions. In this context, we can say that social media users firstly research in the social media platforms about tourism product and services. At the same time, the consumers believe that they can reach a reliable information about tourism product and service. However in this point, if the information is given from tourism business, the trust to the information is decreasing.

In the study, it was seen that social media users were affected by experiences and ideas shared while buying not just tourism product but all product. Also, the consumer getting service advertises more efficient than the business. Because the consumer buying the product or service and using it is the example for other consumers and $\mathrm{s} /$ he effects more their decision. In terms of tourism product, it was understood from the expressions made to state the effects of social media in purchasing process that if consumer is pleased after purchasing, $s /$ he shares this in social media. But the users are in mostly tendency to share their dissatisfactions. So tourism business must take these into consideration and they must closely follow the social media to learn what the consumers consider in purchasing process of tourism product and service. However, it is necessary to implement on the consumer societies with different socio-demographic characteristics in order to develop the research topic. The increasingly competitive conditions of tourism enterprises are bringing effective use of social media by businesses. Therefore, tourism businesses should employ educated staff who can closely follow comments and shares in the social media. This work is limited to 455 social media users. If the sample of future work is larger, it will have more validity to represent the universe. Since the socio-cultural and demographic characteristics of social media users can change, the consumer behavior of social media in psychology and sociology areas can be examined and effective results can be achieved between multidisciplines. 


\section{References}

Akar, E., (2010). Sosyal Medya Pazarlaması: Sosyal Webde Pazarlama Stratejleri. Ankara: Efil Yayinevi.

Akar, E., Topçu, B., (2011). “An Examination of the Factors Influencing Consumers' Attitudes Toward Social Media Marketing”. Journal of Internet Commerce (10), 35-67.

Akyol, M., Kılınç Ö., (2014). İnternel and Halal Tourism.Internatıonal, Periodical For The Languages, Literature and History Of Turkısh or Turkic. 9 (8):171-186

Aymankuy, Y., Soydaş, M.E., Saçlı, Ç. (2013). Sosyal Medya Kullanımının Turistlerin Tatil Kararlarına Etkisi: Akademik Personel Üzerinde Bir Uygulama, International Journal of Human Sciences, 10 (1), 376-397.

Battallar, Z., Cömert, M. (2015). "Tüketicilerin tercihlerinde sosyal medyadaki reklamların etkisi", Turizm Akademik Dergisi, 2 (1),39-48.

Bayazıt Hayta, A., (2008). "Turizm Pazarlamasında Tüketici Satın Alma Süreci ve Karşılaşılan Sorunlar”, Kastamonu Eğitim Dergisi, Mart (16): 31-48.

Bayram, M., Bayram, Ü., Arıcı, S. (2016). “Otel işletmeleri ınstagram paylaşımlarının sosyal medya pazarlaması kapsamında içerik analizi yöntemi ile değerlendirilmesi”, İşletme araştırmaları dergisi, 8(2), 427-442.

Bhatnagar, A., Ghose, S., (2004). "Online information search termination patterns across product categories and consumer demographics", Journal of Retailing, Vol. 80 No. 3, pp. 221-228.

Bizirgiannia, I., Dionysopouloub P. (2013), “The influence of tourist trends of Youth Tourism through Social Media (SM) \& Information and Communication Technologies (ICTs)", Social and Behavioral Sciences, 73, 652-660.

Blackshaw, P., Nazzaro, M., (2006). "Consumer-Generated Media (CGM) 101: Wordof-Mouth in the Age of the Web-fortified Consumer", Nielsen BuzzMetrics, New York, NY.

Borges, B., (2009). "Marketing 2.0 Bridging the Gap Between Seller and Buyer Through Social Media Marketing", Published by Wheatmark.

Boyd, Dannah, M., Ellison, Nicole B., (2007). "Social network sites: Definition, History, and Scholarship", Journal of Computer-Mediated Communication 13(1): 210-230.

Bozatl1, N., Z., (2011). "Sosyal Medya Furyası!”, http://www.turizmguncel.com/makale/sosyal-medya-furyasi--m63.html,

Brady, P., (2010). "Using social media to grow your business", available at: http://ezproxy.fiu.edu/login?urlhttp://search.proquest.com/docview/356998560?ac countid10901

Buhalis, D., Licata, M.C., (2002). “The Future E-Tourism Intermediaries” ,Tourism Management, 23(3),:207-220.

Chan, N. L., Gu1llet, B. D., (2011). "Investigation of social media marketing: how does the hotel industry in Hong Kong perform in marketing on social media websites?", Journal of Travel \& Tourism Marketing, 28(4), 345-368. 
Chung, D., (2008). "Interactive features of online newspapers: identifying patterns and predicting use of engaged readers", Journal of Computer Mediated Communication, Vol. 13 No. 3, pp. 658-679.

Chung, J.Y., BUHALİS D., (2008). "Information Needs In Online Social Networks", Information Tecnology\&Tourism,10(4):267-282

Cox C. , Burgess, S. , Sellitto, C. ve Buultjens, J. (2009), "The Role of User-Generated Content in Tourists' Travel Planning Behavior",Journal of Hospitality Marketing \& Management , 18:743-764

Çetinsöz, B., Akdağ, G. (2015), "Yerli Turistlerin Tatil Sürecinde Sosyal Medya Kullanımı Ve Tatil Kararlarına Etkisi”, I. Eurasia International Tourism Congress: Current Issues, Trends, and Indicators (EITOC-2015),649-662.

Edosomwan, S., Sitalaskshmi, K.P., Kouame, D., Watson, J. and Seymour, T., (2011), "The history of social media and its impact on business", Journal of Applied Management and Entrepreneurship, Vol. 16 No. 3, pp. 79-91.

Erol, G., (2009). "Medya Ve Etik: İnternet Haberciliğinde Nesnellik, Etik İlkelerın İçeriği, Uygulamadaki Sorunlar Ve Televizyon Haberciliği İle Karşılaştırılması", Frrat Üniversitesi Medya ve Etik Sempozyumu, 07-09 Ekim,Elazığ.

Erol, G., Hassan, A. (2014). "Gençlerin Sosyal Medya Kullanımı ve Sosyal Medya Kullanımının Tatil Tercihlerine Etkisi”, Uluslararası Sosyal Araştırmalar Dergisi, 7 (31), 804-812.

Eröz, S., Doğdubay M.(2012). “Turistik Ürün Tercihinde Sosyal Medyanın Rolü ve Etik İlişkisi”, Dokuz Eylül Üniversitesi Iktisadi ve idari bilimler fakültesi dergisi. 27(1):133-157

Eryılmaz, B., Zengin, B. (2014). "Sosyal medyada konaklama işletmelerine yönelik tüketici yaklaşımları üzerine bir araştırma", İşletme Bilimi Dergisi, 2 (1),147-167.

Fisk, R. P., (1981). "Toward a consumption/evaluation process model for services", in Donnelly, J.H. and George, W.R. (Eds), Marketing of Services, American Marketing Association, Chicago, IL, pp. 191-195.

Fotis, J., Buhalis, D., Rossides, N., (2012). "Social Media Use and Impact during the Holiday Travel Planning Process", Springer-Verlag, Berlin, pp. 13-24.

Fotis, J., Buhalis, D., ve Rossides, N. (2012). "Social Media Use and Impact during the Holiday Travel Planning Process", Information and Communication Technologies in Tourism 2012 . In M. Fuchs, F. Ricci \& L. Can (pp.13-24): Springer Vienna.

Goeldner, C., Ritchie, J., Brent, R., (2011). Tourism: Principles, Practices, Philosophies, John Wiley \&Sons, Inc, New Jersey.

Gretzel, U., Dinhopl, A., (2014). "Breaking up is hard to do: why do travelers unlike travel-related organizations?", Information and Communication Technologies in Tourism, p. 267.

Gretzel, U., Fesenmaier, D.R., (2012). "Customer relations 2.0 - implications for destination marketing", paper presented at the TTRA Annual International Conference, VA Beach.

Gretzel, U., Fesenmaier, D.R., O'leary, J., (2006). "The Transformation of Consumer Behaviour, Tourism Business Frontiers: Consumer, Products and Industry", Burlington, MA: Elsevier, p. 9-18. 
Gretzel, U., Yoo, K.H., Purifoy, M., (2007). "Online Travel Review Study: Role\&Impact of Online Travel Reviews, Laboratory for Intelligent System in Tourism", $\quad$ http://Www.Tripadvisor.Com/Pdfs/Onlinetravelreviewreport.Pdf (Erişim:06. 12. 2016)

Gursoy, D., McCleary, K.W., (2004). “An integrative model of tourists' information search behavior", Annals of Tourism Research, Vol. 31 No. 2, pp. 353-373.

Güleç, E., (2016). “Turizm İşletmeciliği Ve Otelcilik Anabilim Dalı Kullanım Ve Doyumlar Yaklaşımının Sosyal Medya Kullanım Niyeti Ve Turistik Deneyim Üzerindeki Etkisinin Belirlenmesi" , Balıkesir Üniversitesi Sosyal Bilimler Enstitüsü Yüksek Lisans Tezi.

Hudson, S.,Thal, K., (2013). "The impact of social media on the consumer process: Implications for tourism marketing", Journal of Travel \& Tourism Marketing, Retrieved from http://dx.doi.org/10.1080/10548408.2013.751276

İşlek, M. S., (2012). "Sosyal Medyanın Tüketici Davranışlarına Etkileri :Türkiye'deki Sosyal Medya Kullanıcıları Üzerine Bir Araştırma”, Karamaoğlu Mehmetbey Üniversitesi, İşletme Ana Bilim Dalı, Yüksek Lisans Tezi.

Jurvetson, S., (2000). From the Ground Floor What Exactly is Viral Marketing?, Red Herring, Red Herring Communications, pp. 110-111.

Kaikati, A. M., Kaikati, J.G., (2004). "Stealth Marketing: How to Reach Consumers Surreptitiously", California Management Review, Vol. 46, No. 4, pp. 6-22.

Kaplan, M. A., Haenlein, M., (2010). "Users of the world, unite! The challenges and opportunities of social media." Business Horizons. 53(1): 59-68.

Kasavana, M.L., Nusair, K.,Teodosic, K., (2010). “Online social networking: redefining the human web", Journal of Hospitality and Tourism Technology, Vol. 1 No. 1, pp. 68-82.

Kazançoğlu, İ., Üstündağlı, E., Baybars, M. (2012). "Tüketicilerin sosyal ağ sitelerindeki reklamlara yönelik tutumlarının satınalma davranışları üzerine etkisi: Facebook örneği”, International Journal of Economic and Administrative Studies, $4(8), 159-180$.

Keskin, S., Baş, M. (2015). "Sosyal medyanın tüketici davranışları üzerine etkisinin belirlenmesi", Gazi üniversitesi iktisadi ve idari bilimler fakültesi dergisi, 17(3), 51-68.

Kienle, H. M., Lober, A.,Vasiliu, C. A., Müller, H. A., (2010). "Investigating the Concept of Consumers as Producers in Virtual Worlds: Looking through Social, Technical, Economic, and Legal Lenses. İçinde: Lehmann-Grube, F. anSablatnig, J. (Eds.), Facets of Virtual Environments. Lecture Notes of the Institute for Computer Sciences, Social Informatics and Telecommunications Engineering (LNICST, New York: Springer. 187-202.

Köksal, Y., Özdemir, Ş., (2013). “Bir İletişim Aracı Olarak Sosyal Sosyal Medya’nın Tutundurma Karması İçerisindeki Yeri Üzerine Bir İnceleme”, Süleyman Demirel Üniversitesi İktisadi ve İdari Bilimler Fakültesi Dergisi,18(1):323-337.

Kükrer Aydın, Ö. (2014). http://akademikstok.com/turkiye'de-otelcilik-sektorundesosyal-medyanin-kullanimina-yonelik-bir-inceleme-oku-37.html.

Law R., Leung K. ve Wong J.(2004)."The Impact Of The Internet On Travel Agencies", International Journal of Contemporary Hospitality 
Management,16(2):100-107.

Lee, D. H. (2010). "Korean consumer \& society: growing popularity of social media and business strategy", SERI Quarterly, Vol. 3 No. 4, pp. 112-1179.

Litvin, S.W., Goldsmith, R.E., Pan, B., (2008). "Electronic word-of-mouth in hospitality and tourism management", Tourism Management, Vol. 29 No. 3, pp. 458-468.

Lovelock, C.W., (2011). Services Marketing: People, Technology, Strategy, 7th ed., Prentice Hall, Upper Saddle River, NJ.

Mangold, W.G., Faulds, D. J., (2009). "Social Media: The New Hybrid Element Of The Promotion Mix", Kelley School of Business, Indiana University, Business Horizons 52:(4)357-365.

Mattila, A.S., Wirtz, J., (2002). "The impact of knowledge types on the consumer search process: an investigation in the context of credence services", International Journal of Service Industry Management, Vol. 13 No. 3, pp. 214-230.

Milano, R., Baggio, R., Piattelli, R., (2011). "The Effects of Online Social Media on Tourism Websites". 18th International Conference on Information, Technology and Travel \& Tourism. Innsbruck, Austria. 26-28 January.

Minghenti, V., Buhalis, D., (2010). Digital Divide In Tourism, Journal Of Travel Research, 49(3):267-281.

Mohamed, A.N., (2012). “An investigation of hoteliers' attitudes toward the use of social media as a branding tool", International Journal of Marketing Studies, Vol. 4 No. 4, pp. 93-105.

Munar, A. M., Jacobsen, J. K., (2014). Motivations for Sharing Tourism.

O’Connor, P., (2008)."Online social media and travel International-September 2008Market research report

http://oxygen.mintel.com/sinatra/oxygen/display/id=387948. Erişim Tarihi: 06.12.2016.

Özdemir, G., Sarı, Ö., (2014). "Turist Destinasyonlarına Dönük Sosyal Medya Söylentileri Üzerine Bir Durum Çalışması”, İstanbul Ticaret Üniversitesi Sosyal Bilimleri Dergisi, 13(25), p. 289-299

Palmer, A., Koening-Lewis N., (2009). "An Experiental, Social Network-Based Approach to Direct Marketing", Direct Marketing: An International Journal, 3(3):162-176.

Papacharissi, Z., (2009). "The virtual geographies of social networks: a comparative analysis of Facebook, LinkedIn and ASmallWorld." New Media Society (11): 199

Pesonen, J. (2012). Social Media Channel Segmentation of Tourists, e-Review of Tourism Research (eRTR), 10 (2), 67-71.

Pietro, L., Virgilio, F., Pantano, E. (2012). Social Network for The Choice of Tourist Destination: Attitude and Behavioural Intention, Journal of Hospitality and Tourism Technology, 3 (1),60-76.

Ráthonyi, G. (2013). Influence Of Social Media On Tourism - Especially Among Students of The University Of Debrecen, Applied Studies in Agribusiness and Commerce-APSTRACT, 7 (1), 105-112. 
Saperstein, J., Hastings, H., (2010). "How social media can be used to dialogue with the customer", Ivey Business Journal Online, Vol. 74 No. 1, p. 6.

Shih, C., (2009). "The Facebook era: Tapping Online Social Networks To Build Better Products", Reach New Audiences, and Sell More Stuff ,1 , Boston, MA: Prentice Hall.

Thomas, D., (2010), "Social media in hospitality", Caterer \& Hotelkeeper, Vol. 200 No. 4649, pp. 33-34.

Toksarı, M., Mürütsoy, M., Bayraktar, M. (2014), Tüketici Algılarını Etkileyen Faktörlerde Sosyal Medyanın Rolü: Niğde Üniversitesi İ.İ.B.F. Örneği, Uşak Üniversitesi Sosyal Bilimler Dergisi, 7 (4), 1-28.

Tsiotsou, R.H., Wirtz, J.,(2012). "Consumer behavior in a service context”, in Wells, V. And Foxall, G. (Eds), Handbook of New Developments in Consumer Behavior, Edward Elgar Publishing, Cheltenham.

Turizm ve Yatırım Dergisi, (2014). "Sosyal Medya Turizmde Pazarlamanın Tanımını Değiştiriyor”, Turizm ve Yatırım İşletme ve Endüstri Dergisi, (24), s. 10-22.

Uygur, S., (2007). Turizm Pazarlaması, Nobel Yayın Dağıtım,İstanbul.

Wheeler, B., (2009). A Guide to Social Networking and Social Media for Tourism.

Wheeler, B., (2012). A Guide To Social Networking And Social Media For Tourism.

Xiang, Z., Gretzel, U., (2010), "Role of social media in online travel information search", Tourism Management, Vol. 31 No. 2, pp. 179-188.

Xiang, Z., Woeber, K., Fesenmaier, D.R., (2008). "Representation of the online tourism domain in search engines", Journal of Travel Research, Vol. 47 No. 2, pp. 137150.

Ye, Q., Law, R., Gu, B., (2009). "The impact of online user reviews on hotel room sales", International Journal of Hospitality Management, Vol. 28 No. 1, pp. 180182.

Živković, R., Gajić, J., Brdar, I., (2014). “The Impact of Social Media on Tourism”, SINTEZA, 758-761.

\section{Internet Resources}

http://www.aktuelmarmaris.com/makaleler.asp?yazar=2790\&yazi=74214, 06.12.2016 tarihinde alınmıştır.

http://www.mustafakirca.com/sosyal-medya-ve-turizm-pazarlamasi.html $\quad 06.12 .2016$ tarihinde alınmıştır.

www.socialmediadefined.com/what-is-social-media.

06.12 .2016 